\title{
Syncope: definíciók, osztályozás, diagnosztika
}

\author{
Lőrincz István
}

\author{
Debreceni Egyetem Általános Orvostudományi Kar, Belgyógyászati Intézet, Sürgősségi Orvostan Tanszék, Debrecen \\ Levelezési cím: Dr. med. habil. Lőrincz István, 4032 Debrecen, Nagyerdei krt. 98. Pf. 19., E-mail: lorincz@belklinika.com
}

A syncope (ájulás, kollapszus) átmeneti eszméletvesztés, az agyi keringés átmeneti, globális hipoperfúziója következtében kialakuló kórkép, amelyre jellemző a hirtelen kezdet, rövid időtartam és a spontán teljes tudatvisszanyerés. A syncope igen gyakran előfordul a klinikai gyakorlatban, és számos oka lehet. Leggyakrabban az ún. reflex, vagy neurálisan mediált mechanizmusok állnak syncope a hátterében. A második leggyakoribb csoport a strukturális eltérésekkel járó szív- és érrendszeri eredetű, magas halálozási aránnyal járó kórképek csoportja. A syncopés beteg ellátása alapvetően megváltozott az elmúlt 20 évben. A szerzők a legújabb eredmények alapján összefoglalják a syncope korszerủ definíciójáról, a klasszifikációról és a klinikai vizsgálati sorrendről ismerteket.

Kulcsszavak: syncope, neurokardiogén, reflex, ortosztatikus, malignus ritmuszavarok, strukturális szívbetegségek

\section{Syncope: definitions, classification, diagnostics}

Syncope is a transient loss of consciousness due to transient global cerebral hypoperfusion, characterised by rapid onset, short duration, and spontaneous complete recovery. Syncope is a common symptom in the clinical practice. Syncope may have a variety of causes. A so called a reflex or neurally-mediated syncope is the most common type of syncope. The second most common causes of syncope are cardiovascular in origin and are associated with a high mortality in patients with underlying heart disease. The evaluation and management of syncope has basically changed over the past 20 years. The authors summarize the most recent knowledge about the definition, classification and evaluation of syncope.

Keywords: syncope, neurocardiogenic, reflex, orthostatic, malignant dysrhythmias, structural heart diseases

A syncope (ájulás, kollapszus) igen gyakori klinikai tünetegyüttes. A prevalenciában 10 és 30 éves kor között mutatkozik kiugrás: a csúcs 15 éves kor körül nőkben $47 \%$, férfiakban $31 \%$. Az előfordulás ezután jelentősen csökken, és 65 éves kor felett emelkedik ismét. A Framingham-study alapján a férfiakban $3 \%$, a nőkben $3,5 \%$ az évenkénti előfordulási gyakoriság. A visszatérő eszméletvesztéses rosszullétek a kórházakban közel egy százalékban szerepelnek a felvétel indokaként, a sürgősségi osztályokon pedig a betegek 3-5\%-a jelentkezik ezzel a panasszal. A populáció 30 százaléka életében legalább egyszer elveszti az eszméletét, a gyakoriság az életkorral nő: 70 év felett az éves incidencia 6 százalék. A gyerekek 15\%-a él át eszméletvesztést, mielőtt elérné a felnőttkort. Az esetek 35\%-ában a syncope során különböző mértékü sérülések (subduralis haematoma, arc- és végtagsérülések) alakulnak ki, ezen kívül pszichés következmények, szorongás, félelmi reakciók is jelentkezhetnek (12).

Számos tanulmány foglalkozik a syncopéban szenvedő betegek egységes ellátására törekvő optimális diag- nosztikájával és kezelésével. A syncopén túl a figyelem gyakran a társuló kórképekre, például az ortosztatikus hipotenzióra irányul. Az ajánlásokat különböző európai, illetve észak-amerikai belgyógyász, kardiológus, neurológus és sürgősségi orvostani társaságok bocsátották ki $(1,2,3,5,6,8,9,10,11,12,16,17,21)$.

Tény, hogy a különböző definíciókban bizonyos különbségek tapasztalhatók, egyes vezérfonalak hangsúlyozzák az eszméletvesztés és az izomtónus elvesztésének kapcsolódását, más ajánlások nem emelik ki ezt a komponenst. Mi a jelenleg érvényes európai ajánlást követve syncopeként a hirtelen jelentkező, átmeneti jellegü eszméletvesztést definiáljuk, amelynek során a beteg poszturális tónusát is elveszti, majd spontán, általában tiszta tudattal magához tér (12). Az ájuláskor bekövetkező tudatvesztés oka az agyi keringés átmeneti globális csökkenése vagy leállása, ami a legtöbbször a szisztémás vérnyomás hirtelen esése kapcsán alakul ki. Legalább $60 \mathrm{Hgmm}$ alá kell csökkennie a szisztolés vérnyomásnak ahhoz, hogy ez az agyi keringést számottevően befolyásolja (12). A definíció min- 
1. TÁBLÁZAT. Helytelenül syncopénak diagnosztizált kórképek, illetve állapotok

\section{Részleges vagy teljes eszméletvesztés, globális cerebrális hipoperfúzió nélkül}

Epilepszia

Metabolikus okok, hypoglykaemia, hypoxia, hiperventillációval járó hypocapnia

Intoxikáció

Vertebrobasilaris TIA

\section{Olyan betegségek, amelyekben nincs valódi} eszméletvesztés

Katalepszia

Drop attak

Elesés*

Funkcionális-pszichogén

Carotis eredetű TIA

*Az ájulás és az elesés kapcsolata összetett, különösen idös betegeknél problematikus, gyakori az átfedés

den eleme fontos. Az eszméletvesztés spontán szűnik, nem igényel beavatkozást, kardioverziót. A syncope relatíve hirtelen alakul ki, bevezető tünetei, ha egyáltalán jelentkeznek, 10-20 másodpercnél rövidebbek. Egyes formákban a bevezető tünetek jellegzetesek és informatívak (pl. szédülés, hányinger, verejtékezés, gyenge- ség, távoli hangok hallása, látászavarok, egyenetlen és/vagy szapora szívmüködés stb.), azonban azok teljes hiánya sem ritka - így például az időskori ájulásoknál. A poszturális tónus elvesztése eldőléshez, eleséshez vezet. Az ájulás átmeneti, rövid ideig tart. A teljes eszméletvesztés vazovagális syncopéban rendszerint nem tart tovább 20 másodpercnél, az ájulás időtartama azonban olykor hosszabb lehet, esetleg percekig is tart. llyenkor elkülönítése az eszméletvesztés egyéb okaitól nehezebb feladat. A mindennapi klinikai gyakorlatban magának az „eszméletvesztésnek” az értelmezése is gondot okozhat, s ez téves syncope diagnózishoz vezethet (5). A differenciáldiagnosztikai gondokat okozó kórképeket az 1. táblázat foglalja össze (12).

A presyncope megnevezés olyan állapotra utal, amelyben a betegek úgy érzik, hogy az ájulás közeleg, rögtön bekövetkezik. A presyncopéhez társuló jelek általában aspecifikusak (pl. bizonytalanságérzés, szédülés, gyengeségérzés), és nagy átfedést mutathatnak a valódi ájulást beharangozó, korábban említett tünetekkel. A részleges vagy teljes eszméletvesztéssel járó nem syncopés epizódok közül a legfontosabb a görcsroham. Amíg a rosszullét természetét nem tisztázzuk, leghelyesebb, ha a syncope helyett a tágabb értelmü „átmeneti eszméletvesztés” („transient loss of consciousness”; TLOC) kifejezést használjuk $(5,15)$. A 2009-es európai és a legújabb 2017-es amerikai irányelv felhívja a figyel-

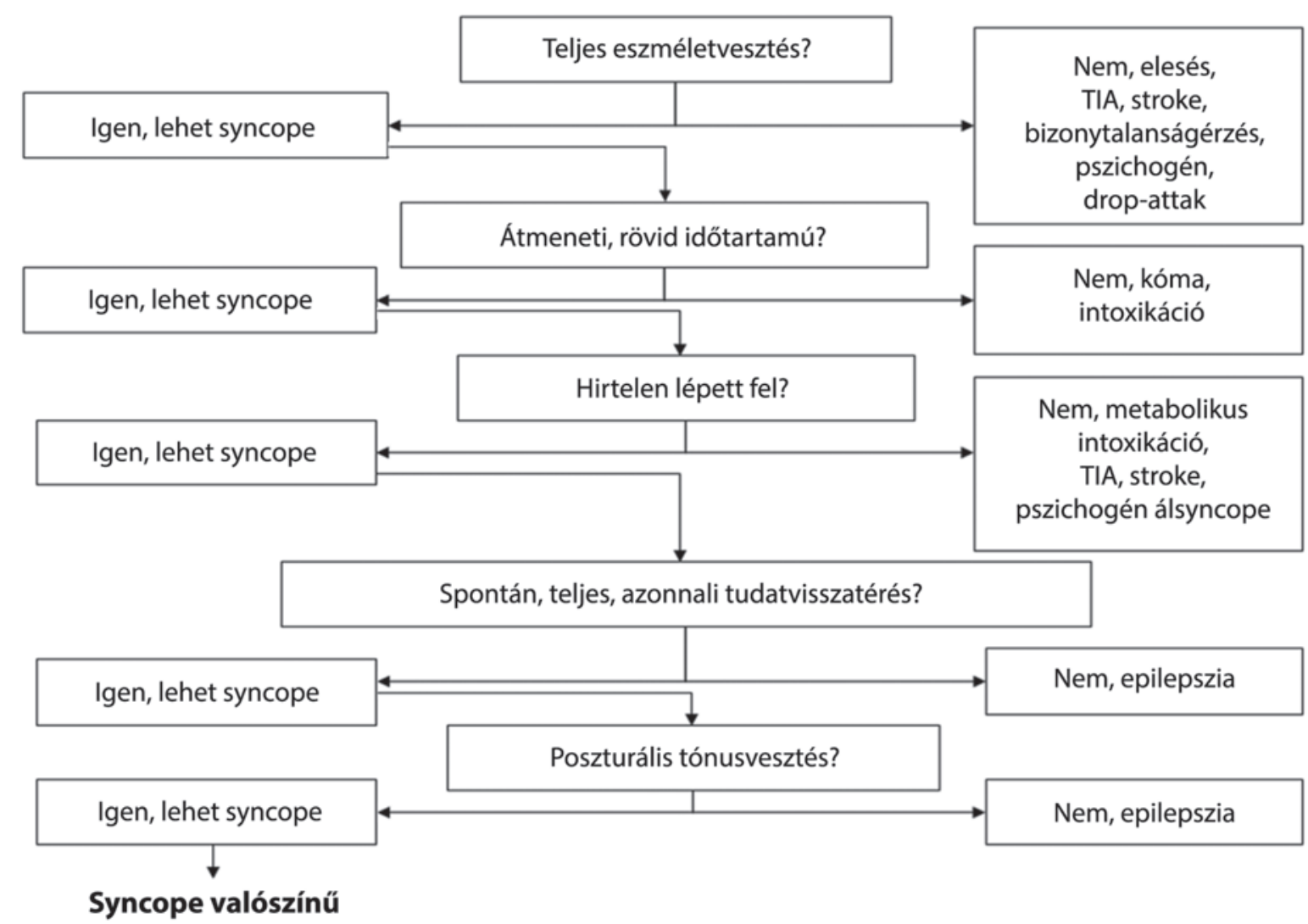

1. ÁBRA. Az átmeneti eszméletvesztés (TLOC) megközelítésének lépései, a syncope megerősítése 


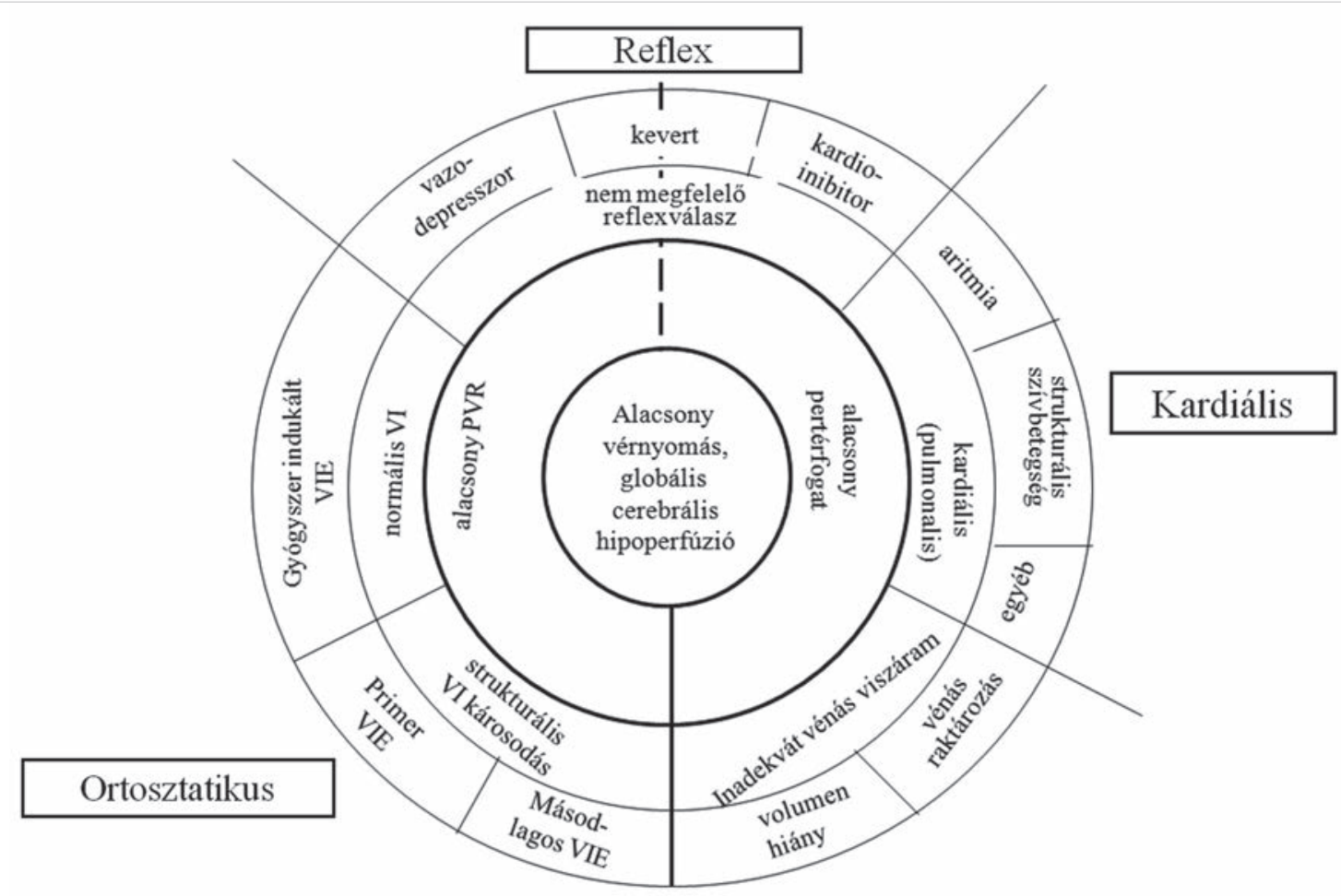

2. ÁBRA. A syncope klinikai megjelenési formái, és az azok hátterében álló, egymással folyamatosan szövődő, kombinálódó mechanizmusok. Rövidítések: VI: vegetatív idegrendszer; VIE: vegetatív idegrendszer eltérései; PVR: perifériás vaszkuláris rezisztencia; $\mathrm{OH}$ : ortosztatikus hipotenzió

met a definícióra és az elkülönítő diagnosztikára (12, 21). A TLOC felosztását, illetve a gyors döntés szempontjából fontos szempontokat az 1. ábra mutatja be.

\section{A syncope mechanizmusai}

A syncope kialakulásában szerepet játszó patofiziológiai folyamatokat a 2. ábra foglalja össze. Azonnal megjegyzendő, hogy a való életben a különböző tényezők gyakran társulnak, szövődnek egymással (12).

A 3. ábra kördiagramjának közepén helyezkedik el a szisztémás vérnyomásesés, amely kiváltja a syncope kórélettani hátterét képező globális cerebrális hipoperfúziót (12). Az agyi keringés mintegy 6-8 milliszekundumos megszakadása, vagy megszünte már elégséges arra, hogy kialakuljon az eszméletvesztés. A szisztémás vérnyomást a perctérfogat és teljes perifériás vaszkuláris rezisztencia határozza meg, s ha a kettő közül valamelyik kritikus mértékben csökken, létrejön az ájulás. Számos esetben bizonyítható mindkét mechanizmus kóroki szerepe, még akkor is, ha részvételi arányuk szinte állandóan változik a folyamatban.

Az epizódszerüen jelentkező alacsony perctérfogatot három tényező magyarázhatja. Az első lehetséges ok a keringési következményekkel járó brady-, vagy tachycardia. Normálisan létezik egy viszonylag széles sáv, nagyjából 40/perc és 190/perc határok között, ahol a pulzusszám változása a verőtérfogat ellentétes irányú változásával jár, s a perctérfogat megtartott marad. A határértékek alatt, illetve felett már perctérfogat-csökkenés következhet be. A második lehetőség az, amikor a szív maga képtelen megfelelő perctérfogatot generálni. Ennek hátterében állhat pumpaelégtelenség, bal, illetve jobb szívfelet érintő obstrukciós kórkép, vagy perikardiális tamponád. Megjegyzendő, hogy a kontraktilis funkció zavara önmagában még akut súlyos formában sem szokott szükségszerüen ájuláshoz vezetni, a syncope hátterében ilyenkor is többnyire társmechanizmus, (például aritmia) áll. Az átmeneti perctérfogat-csökkenés harmadik potenciális oka az elégtelen vénás visszaáramlás, amit okozhat tényleges súlyos volumenhiány, vagy a venomotor tónus zavara.

Alacsony perifériás vaszkuláris rezisztencia kialakulhat kóros reflexaktivitás révén. A vazodilatáció, a bradycardia mellett, vagy önmagában, a reflex syncope egyik fő mechanizmusa. A reflex syncopéban a vazodilatáció persze a vénás oldalon is jelentkezik, így a reflex syncopéban észlelt vérnyomásesés nemcsak az a kórosan csökkent artériás rezisztenciát, hanem a korábbiakban már említett csökkent vénás visszaáramlást is jelezheti. A fenti kóros (fokozott, illetve paradox), reflexválasszal szemben létezik elégtelen, (inadekvát) perifériás vaszkuláris rezisztenciaválasz is, így az autonóm idegrendszer funkcionális, vagy strukturális károsodásában, illetve gyógyszerhatás következtében. Az elégtelen vá- 

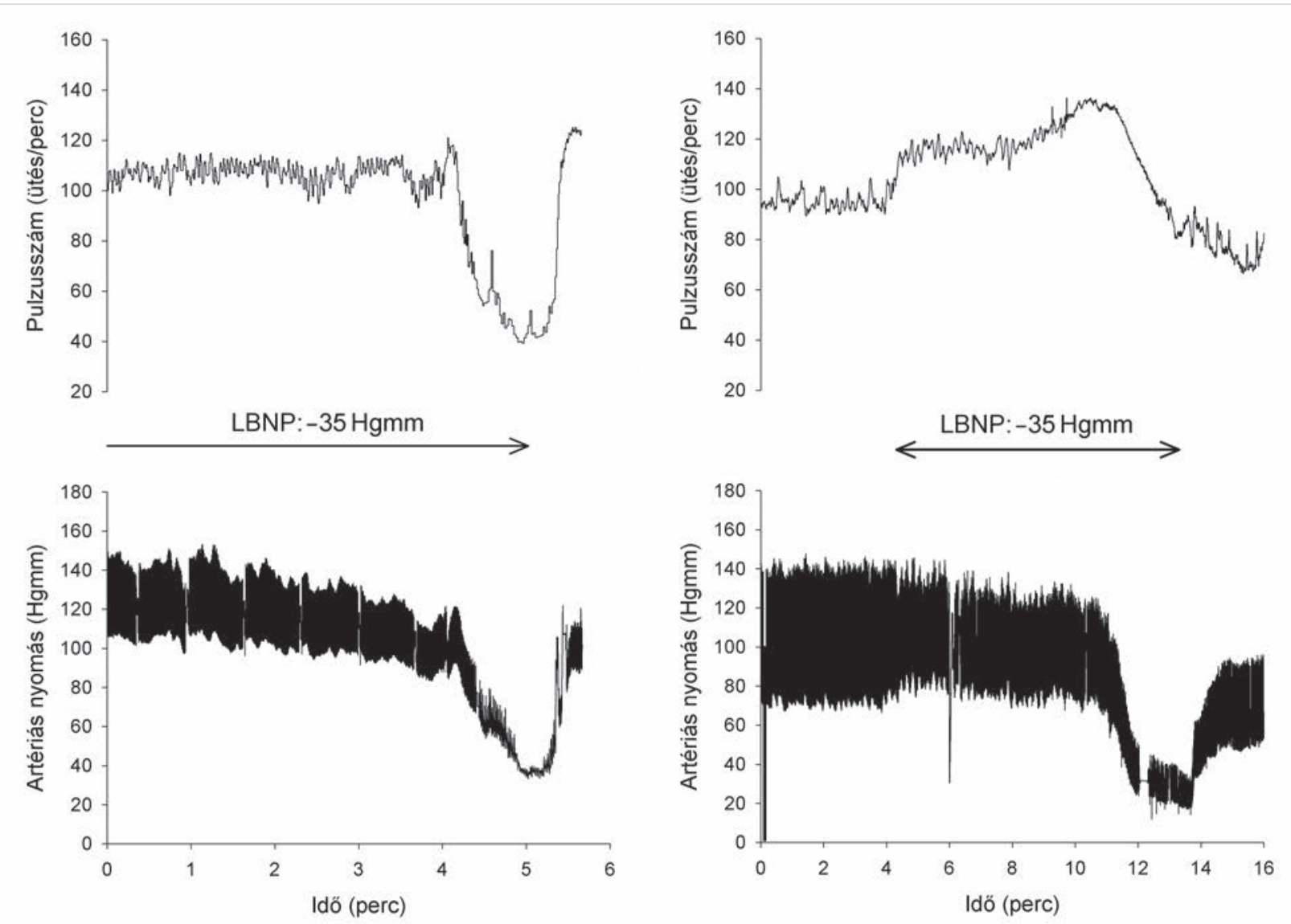

3. ÁBRA. A két hemodinamikai regisztrátum fiatal, vazovagális syncopéban szenvedő alanyok centrális hypovolaemiára adott válaszait mutatja be. A terhelést vákuum kamrában, alsó testfél negatív nyomással (-35 Hgmm) végeztük, ez nagyjából megegyezik a függőleges testhelyzet okozta terheléssel. A bal oldali panel kevert-, a jobb oldali egy kardioinhibitoros syncope kialakulását demonstrálja. Rövidítés: LBNP: lower body negative pressure. (Prof. dr. Rudas László anyagából)

lasz elsősorban felegyenesedett testtartásban mutatkozik meg. Ilyenkor a fokozott vénás raktározás miatt csökken a vénás visszaáramlás, következményesen pedig a perctérfogat. A szimpatikus vazomotor rendszer azonban e betegekben képtelen a megfelelő artériás nyomás fenntartásához a vaszkuláris rezisztenciát kellően megnövelni.

\section{A syncope típusai; klasszifikáció}

A korábbiakban már jeleztük, hogy a syncope patofiziológiai folyamatai gyakran szövődnek egymással, ezért a képeket olykor nehéz szigorúan egy-egy kategóriába sorolni. A felosztás jelentőségét inkább az adja, hogy a prognózis szorosan összefügg az ismert, vagy az eladdig éppen ismeretlen alapbetegséggel. A potenciálisan kardiális eredetű ájulás fel nem ismerése a beteg életébe kerülhet, de a benignus vazovagális syncope túlértékelése, s a felesleges diagnosztikus procedúrák halmozása ugyancsak hiba. Az egyes ájulási kategóriák részletes bemutatása terjedelmi okokból itt nem lehetséges, és a kardiális syncopék bemutatása sem állhat arányban azok klinikai jelentőségével, súlyával (1, $12,13,15,21)$.

Az ájulások mintegy 15\%-a kardiális, (kardiovaszkuláris) syncope, s ezek hátterében leggyakrabban aritmia áll. Az aritmiás syncope kialakulásában több tényező szerepelhet. A szívfrekvencia és a verőtérfogat öszszefüggéseiről már szót ejtettünk, további fontos faktor lehet a normális pitvar-kamrai szinkronitás megléte-, vagy annak hiánya, a balkamra-funkció, a testhelyzet, továbbá a perctérfogat-csökkenésre adott vaszkuláris kompenzáció épsége. Koszorúér-betegségben, illetve dilatatív cardiomyopathiaban a syncope általában nem az első tünet, a kórelőzmény azonnal helyes irányba terel bennünket, s a további teendőket a kardiológiai, illetve szív elektrofiziológiai vizsgálatok leletei határozzák meg. A hipertrófiás cardiomyopathiának azonban lehet az első megnyilvánulása az ájulás, vagy a hirtelen halál (17). Hasonló a helyzet az aritmogén jobb kamrai cardiomyopathiával is. Mindkét állapotban előfordulhat terheléssel összefüggő ájulási epizód, ezt a prezentációt mindig erős gyanúval kell kezelnünk. Az ájulás, mint első klinikai esemény, ugyancsak jellemző lehet az ioncsatorna-betegségekre - a hosszú QT-szindró- 
mák családjára és a Brugada-szindrómára, - s a hirtelen halállal való összefüggés ugyancsak egyértelmü. $E$ kórképek EKG-jeleinek ismerete nélkülözhetetlen, felismerésük a betegség kimenetelét befolyásoló tényező. A fenti képek és a syncope összefüggését illetően az olvasó további részleteket találhat az amerikai 2006-os és 2017-es ajánlásokban (17, 21).

Strukturális kardiovaszkuláris kórképek akkor okozhatnak syncopét, amikor a betegség következtében kritikus mértékben csökken a szív által generált perctérfogat. Jellemző példa erre a fix-, vagy dinamikus bal kamrai obstrukcióval járó kórképekben kialakuló ájulás. Fel kell hívni a figyelmet azonban, hogy még ezekben a kórképekben is szerepet játszhatnak egyéb tényezők. Valvuláris aortastenosisban például nemcsak a csökkent perctérfogat, hanem a paradox reflexes vazodilatáció, illetve primer szívritmuszavar is állhat az ájulás hátterében (12). Megjegyzendő, hogy a súlyos aortabillentyű-szükülettel összefüggő ájulás a komponens mechanizmusoktól függetlenül igen nagyfokú rövid távú mortalitási kockázatot jelez. Ugyancsak lehet reflexes komponense a tüdőembóliában bekövetkező ájulásnak, de a syncope itt is nagy kockázatra utal.

A reflex-, vagy neurálisan mediált ájulások jelentősége elsősorban gyakoriságukban rejlik, az esetek $70 \%$-a tartozik e csoportba. A reflex syncope családjába a vazovagális-, a szituációs és a carotis sinus syncope mellett bizonyos atípusos, (leginkább tilt-teszttel kiváltható) syncope formákat sorolunk. A vazovagális syncope, az úgynevezett közönséges ájulás, rendszerint emocionális stresszre, vagy ortosztatikus terhelésre adott válaszként lép fel. Többnyire bevezető tünetek (prodroma) előzik meg, amelyek a vegetatív idegrendszeri aktivációra utalnak (verejtékezés, sápadtság, hányinger). A szituációs syncope kifejezést hagyományosan olyan ájulásokra alkalmazzuk, amelyek speciális körülmények között lépnek fel. Olyan képeket is besorolunk ebbe a csoportba, amelyekben a reflex mechanizmusok mellett az intrathoracalis nyomásfokozódás közvetlenül is az agyi perfúzió kritikus csökkenéséhez vezethet (ilyen például a trombitafújás, súlyemelés, köhögés, vagy a mikturíció során fellépő syncope). Régóta ismert, hogy a súlyos kivérzés bizonyos pontján paradox reakció léphet fel, amely a vazovagális syncopével analóg jelenség. E forma változatának tekinthető a fiatal sportolók terhelést követő, álló testhelyzetben fellépő rosszulléte. Ekkor az izompumpa müködésének megszüntével a vér a tágult érrendszerben „veszik el”. A carotis sinus syncope során a baroreceptív területek közvetlen ingerlésével nem paradox, hanem rendellenesen fokozott választ váltunk ki. Olykor egyértelmü anamnesztikus adat bizonyítja, hogy a páciens rosszullétét valamilyen mechanikus nyaki stimulus váltotta ki, azonban az esetek zömében nem találunk specifikus triggerre utaló adatot, s a képet csak a carotis masszázsra adott válasz bizonyítja $(12,19)$. Klinikailag a reflex syncopék jelentkezhetnek dominálóan kardioinhibítoros-, vazode- pressziós-, illetve kevert mechanizmusú formában (3. ábra) $(1,11,12,18)$. A szigorú osztályozást itt is zavarja, hogy az arra hajlamos alanyokban a visszatérő ájulás eltérő „dominanciát” mutathat, illetve ugyancsak eltérhet a spontán jelentkező, illetve a billenőasztal-teszttel provokált syncope fő mechanizmusa.

Az ortosztatikus hipotenzió $(\mathrm{OH})$ gyakran csak tünet; vérzés vagy egyéb volumenvesztés, illetve gyógyszerhatás állhat a hátterében. Máskor az $\mathrm{OH}$ önálló probléma, és mint ilyen szorosan kapcsolódik az ortosztázis intolerancia képéhez. Ehhez a képhez az ájulás nem szükségszerủen tartozik hozzá, egyéb jellemzői, mint gyengeség, fáradékonyság, látás-, hallás-, vagy kognitív zavarok állhatnak a középpontban. $\mathrm{Az} \mathrm{OH}$ különböző klinikai prezentációkban nyilvánulhat meg $(7,12)$. A klasszikus $\mathrm{OH}$ definíciója szerint a beteg szisztolés vérnyomása álló helyzetben 3 perc elteltével $\geq 20 \mathrm{Hgmm}$ rel-, diasztolés vérnyomása pedig $\geq 10 \mathrm{Hgmm}$-rel csökken. Primer és szekunder autonóm idegrendszeri megbetegedésben, hipovolémiában, illetve gyógyszerek hatására lép fel. Az iniciális $\mathrm{OH}$-ra jellemző, hogy hirtelen felegyenesedéskor (pl. cipőfüzést követően) azonnal lecsökken a szisztolés nyomás (> 40 Hgmm), s általában 30 másodperc után a vérnyomás spontán és gyorsan normalizálódik. Fiatal, aszténiás alkatú egyénekben, illetve idősekben gyógyszermellékhatásként jelentkezik. A késői OH jellemzően idősekben jelentkezik, s a felegyenesedést követő 30-45 perc során fokozatosan alakul ki. Számos tényező járul hozzá, köztük gyógyszerhatás, s különböző súlyosságú autonóm diszfunkció. Csatlakozhat hozzá syncope, de a reflexes bradycardia sokkal lassabban alakul ki, mint a fiatalokban (4. ábra). A poszturális ortosztatikus tachycardia szindróma (POTS), általában a fiatal nők betegsége. Ortosztatikus terhelésük során kellemetlen szubjektív panaszok kíséretében szapora szívmúködés (> 30/min frekvenciaemelkedés, vagy >120/min pulzusszám) jelentkezik. A vérnyomás gyakran ingadozó, instabil, de a valódi ájulás elvileg nem része a képnek. A POTS gyakran társul krónikus fáradtság szindrómával. A háttérben több, egyelöre csak részlegesen ismert patomechanizmus áll (12).

\section{A syncope diagnosztikája}

Az elmúlt 20 évben sokat változott a syncope klinikai kivizsgálásának és kezelésének rendje. Az újabb eszközök és algoritmusok segítségével egyre jobban felismerjük a ritmuszavarral összefüggő, illetve a neurálisan mediált syncopés eseteket $(10,12,16,20,21)$. Időigényes explorációval csökkenthetjük a fel nem ismert pszichiátriai eredetű esetek arányát. Mindezek ellenére, még mindig előfordul, hogy a kórházból történő elbocsátáskor sincs meg a pontos diagnózis. Bár a diagnosztikus megközelítések közvetlen összehasonlításáról nincs adatunk, jól jelzi azok hatásfokát a diagnosz- 

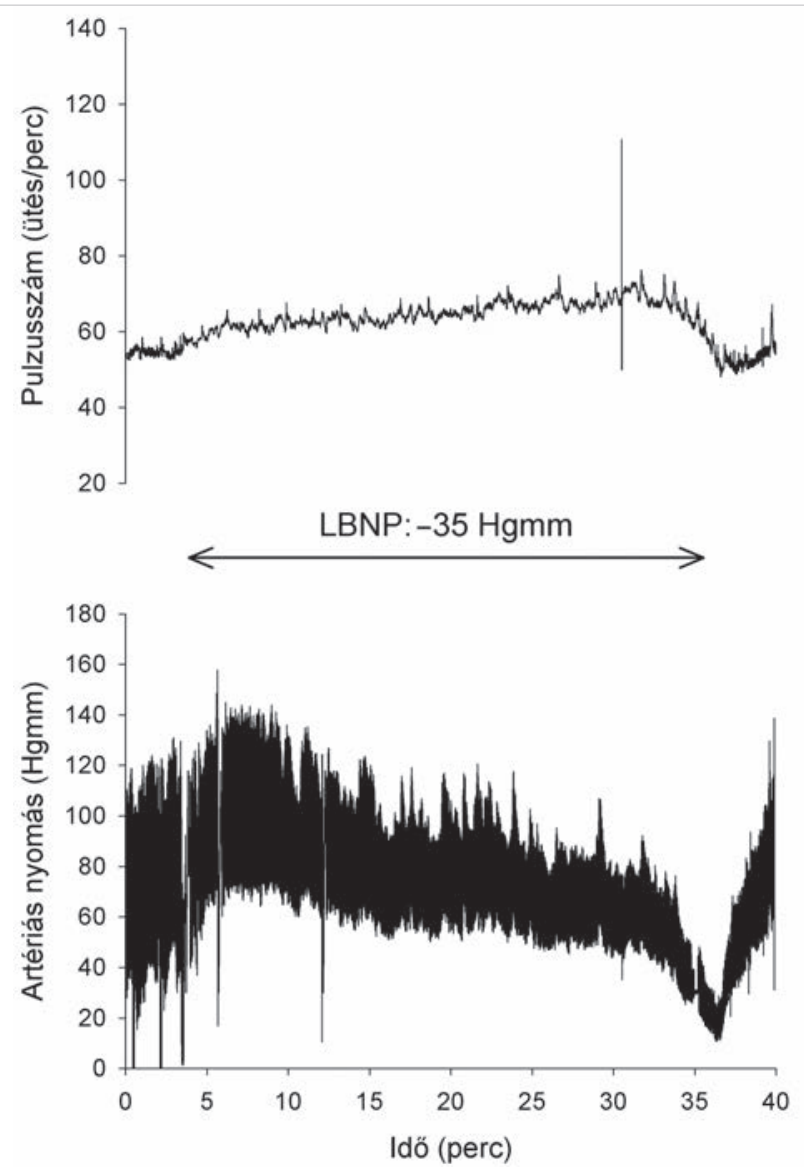

4. ÁBRA. Idős alany vákuum kamrában végzett terhelésre (-35 $\mathrm{Hgmm})$ adott keringési válaszai. A regisztrátum alapján több, egymással kapcsolódó diagnózis is felmerül. Késői OH kialakulása figyelhető meg, ugyanakkor a nagyon limitált pulzusszámválasz kronotróp inkompetenciát jelez. Mindkét jelenség összefügghet autonóm regulációs zavarral - például cukorbetegséghez társuló neuropátiával. Rövidítés: LBNP: lower body negative pressure. (Prof. dr. Rudas László anyagából)

tikus zsákutca; az „ismeretlen eredetű” syncope aránya a kórházi kibocsátáskor. Az alacsony hatásfokú megközelítést a kardiológiai és autonóm vizsgáló eszközök alkalmazásának hiánya, és a kis diagnosztikus értékü ám költséges neurológiai (neurológiai képalkotó) eszközök túlzott igénybevétele jellemzi. Az Európai Kardiológus Társaság 2009-ben felújított ajánlása szerint a diagnosztika egy algoritmus (5. ábra) köré szerveződik (12). A vezérfonal alapgondolatát átvette a Magyar Kardiológusok Társasága és a Magyar Sürgősségi Orvostani Társaság is $(1,11)$. A fentiekkel lényegében megegyezik a legújabb 2017-es amerikai ajánlás is (21).

Valamennyi ajánlás célja, hogy támogassa a jóindulatú és az életveszélyes syncope formák elkülönítését. Az ajánlás megadja a legalapvetőbb diagnosztikus módszereket, felvázolja e módszerek alkalmazásának sorrendjét s végül segít a döntéshozatalban, mikor kell a beteget kórházba felvenni, illetve mikor lehet ambuláns kivizsgálást folytatni $(1,11,12,21)$.
A syncopéban szenvedő betegek kivizsgálása során különféle diagnosztikai eljárások állnak rendelkezésünkre. Az alapvizsgálatokkal (anamnézis, fizikális vizsgálat, fekvő és álló helyzetben végzett vérnyomásmérés - Schellong-teszt - nyugalmi 12 elvezetéses EKG) a valódi syncope és a nem syncopés rosszullét különíthető el. Az utóbbiak pontos természetét célzott vizsgálatok és szakkonzíliumok tisztázzák. A syncopés eredetűnek tartott csoporton belül az alapvizsgálatokkal biztos vagy feltételes diagnózishoz juthatunk, ha továbbra sem ismert a kiváltó ok, az alapvizsgálatokkal nem tisztázott eredetủ syncope terminológiát használjuk $(1,11,12,21)$.

\section{Főbb kórelózményi adatok}

A jó auto- és heteroanamnézis alapján a betegek 45\%ában tisztázható a pontos diagnózis. A családi anamnézis hasznos információt szolgáltathat, korai hirtelen halálra, syncope hajlamra, pacemaker/implantábilis kardioverter defibrillator igényre figyelünk.

A syncopék gyakorisága orientálhat bennünket. Ha az ájulás visszatérően, de nem túl gyakran jelentkezik hosszú évek során, akkor általában jóindulatúnak tartható a kórkép. Az újonnan jelentkező, az utóbbi időben halmozódó syncope inkább rossz prognózisú.

Fontosak a kísérő tünetek. A légszomj, illetve az angina kardiális eredetre utal, a fokális neurológiai tünet idegrendszeri betegségre, a hányinger, hányás, sápadtság, izzadás vagus hatásra, az átmeneti széklet és/vagy vizelettartás-képtelenség pedig epilepsziára lehet jellemző.

A prodróma egyes képekben kórjelző lehet. A gyengeséggel, hányingerrel, sápadtsággal, verejtékezéssel kezdődő rosszullét inkább vazovagális syncopénak tartható, míg a bevezető tünetek nélküli ájulás aritmia gyanúját veti fel. A palpitáció ugyancsak a szívritmuszavar mellett szól. Az aura morbus sacerre utal.

A beteg jellemző ájulási testhelyzete is eligazíthat bennünket. Álló helyzetben fellépő rosszullét jellemzi az ortosztatikus hipotenziót, illetve a közönséges ájulást, a fekvő helyzetben jelentkező syncopét ezzel szemben nagy valószínűséggel aritmia okozza.

Ügyeljünk a kiváltó eseményre. A nyak hirtelen fordítása, köhögés, étkezés, hideg folyadék ivása, vizeletürítés, székelés mind okozhatnak reflex-, illetve szituációs syncopét. Fizikai, pszichés terhelésre jelentkező ájulás hátterében mindig gondoljunk az organikus szívbetegség (ISZB, aortastenosis, obstruktív cardiomyopathia) lehetőségére.

A rosszullét időtartama ugyancsak fontos tényező. A hosszan tartó eszméletvesztést, tudatzavart inkább epilepszia vagy egyéb cerebrovaszkuláris megbetegedés okozza, az aritmia vagy a vazovagális reakció ezzel szemben rövid ideig tartó rosszullétet provokál.

Kapcsolódó kérdés a tünetek megszűnése utáni állapot. Jelentős neurológiai maradványtünet, ködös tudatállapot stroke, illetve epilepszia mellett szól. Aritmi- 
2. TÁBLÁZAT. A syncope jellegzetes klinikai megjelenési formái

\section{Neurálisan mediált ájulások}

Nincs anamnesztikus szívbetegség

Hosszú a syncopés kórelőzmény

A rosszullétet kellemetlen látvány, hang, szag vagy fájdalom provokálja

Hajlamosító a hosszas ácsorgás, illetve a meleg, zsúfolt környezet

Étkezés után jelentkezik

A fej fordítása, a nyak szorítása provokálja

Terhelés után jelentkezik

\section{Ortosztatikus hipotenzió}

Jelentkezhet közvetlen felegyenesedés után, vagy hosszabb-rövidebb ácsorgást követöen

Vérnyomásesést provokáló gyógyszer indításával, dózisnövelésével függhet össze

Ismert autonóm neuropátiához, Parkinson-szindrómához társulhat

\section{Kardiális eredetü syncope}

Ismert súlyos strukturális szívbetegséghez társul

Terhelés során (!) jelentkezik

Fekvő helyzetben lép fel, palpitáció előzi meg vagy mellkasi fájdalom kíséri

A hirtelen halál családi halmozódást mutat

ás eredetű-, vagy közönséges ájulás után nincs ilyen, azonban az utóbbiban gyengeség verejtékezés maradhat vissza, amely órákon keresztül eltarthat. A súlyos sérüléssel járó syncopék hátterében gyakran nagy kockázatú folyamat áll, az elektrofiziológiai vizsgálatok eredménye gyakrabban pozitív, s általában a mortalitás is nagyobb ebben a csoportban. Megjegyzendő, hogy az idősebbek gyakrabban és súlyosabban sérülnek meg, függetlenül a syncopét kiváltó alapfolyamattól.

A szemtanúk kikérdezése fontos feladat. A rosszullét kezdetéről, a lefolyásról, a tudatvisszatérésről értékes adatok nyerhetők, de a hallottakat kezeljük óvatosan. Az ájulással járó globális agyi hipoxia például izomrángásokhoz vezet, s ezt a laikus megfigyelők gyakran nevezik „görcsnek".

A páciens életkora önmagában is irányítja a kivizsgálást. Fiataloknál a közönséges ájulás a gyakori probléma, de megbújnak köztük a hosszú QT-szindrómával, hipertrófiás cardiomyopathiával, vagy aritmogén jobb kamrai diszpláziával összefüggő esetek is. Idősebbeknél a helyzet többnyire összetett. Organikus szív- vagy cerebrovaszkuláris megbetegedésre, carotis syncopéra gondolunk, azonban olykor a társbetegségek nagyon széles körét kell figyelembe vennünk. Pszichiátriai kórkép, cukorbajjal-, vagy alkoholizmussal összefüggő neuropathia, továbbá gyógyszeres kezelés következménye is lehet az ájulás. Az antihipertenzív szerek, a különféle vazodilatátorok, a vízhajtók és az alkohol hipotenziós epizódokra hajlamosítanak. Az antiaritmiás szerek proaritmiás hatásuk révén kerülhetnek gyanúba $(1,11$ 12).

Az anamnézisből nyert információk alapján gyakran jellegzetes prezentációk álíthatók össze, amelyek egyúttal a nyilvánvaló diagnózist is sejtetik. Ezeket röviden a 2. táblázat foglalja össze.

\section{Fizikális vizsgálat}

A fizikális vizsgálat az anamnézis és a 12 elvezetéses EKG mellett az alapvizsgálatok fontos komponense. A fekvő, ülő és álló testhelyzetben (Schellong-teszt) mindkét karon végzett vérnyomásmérés, a pulzusszám és a légzés vizsgálata kulcsfontosságú. A vérnyomásmérést ötpercnyi háton fekvés után kezdjük, s ezt követően egy vagy három perces állás után ismételjük. Ellenőrizzük a légzést, keressük a hipovolémia (gasztrointesztinális vérzés) jeleit. Hallgatózással billentyübetegségek, pericarditis, söntök jeleit kutatjuk. Megítéljük a neurológiai státuszt. Féloldali neurológiai elváltozások vaszkuláris eredetű cerebrális betegségre utalnak, diffúz károsodás jelei inkább kardiális okok következményei $(1,11,20)$.

\section{Biztos vagy feltételes diagnózis}

Az alapvizsgálatok során az anamnézis, a klinikai tünetek, jelek és a nyugalmi 12 elvezetéses EKG-leletek alapján állítható fel szerencsés esetben a biztos diagnózis, nincs szükség további kivizsgálására, a nyert eredmények alapján megtervezhető és kivitelezhető a kezelési stratégia. Gyakran előfordul azonban, hogy az alapvizsgálatok csupán feltételes diagnózist nyújtanak, s a további irányított speciális vizsgálati módszerekkel kell alátámasztani a diagnózist $(12,20,21)$.

\section{Alapvizsgálatokkal nem tisztázott eredetú syncope}

Ez a betegcsoport a fejlődő diagnosztikus módszerek ellenére változatlanul komoly kihívást jelent. Az idős, számos társbetegséggel rendelkező betegek aránya a fejlett országokban egyre nő, s pontosan ők azok, akiknél a kivizsgálás gyakran holtpontra jut. Sokszor nem az a probléma, hogy egyáltalán nincs potenciális magyarázat az ájulásra, hanem az, hogy melyik a lehetőségek közül az igazi ok. A legfontosabb kérdés, hogy kimutatható-e náluk strukturális szívbetegség és/vagy kóros EKG-elváltozás. Ha igazolható, akkor az aritmiarizikó és az egyéves mortalitás is nagyobb. Ekkor részletes kardiológiai kivizsgálás szükséges, amelynek eszközei az echokardiográfia, a terheléses vizsgálatok, sz.e. 24-48 órás ambuláns Holter EKG-, illetve hoszszabb idejü eseményrögzítő EKG-monitorozás, klinikai szív elektrofiziológiai vizsgálat $(11,12,16,21)$. (A tartós eseményrögzítő EKG-monitorozás újabb fejleményeit a csatlakozó társközlemény részletesen mutatja be). 


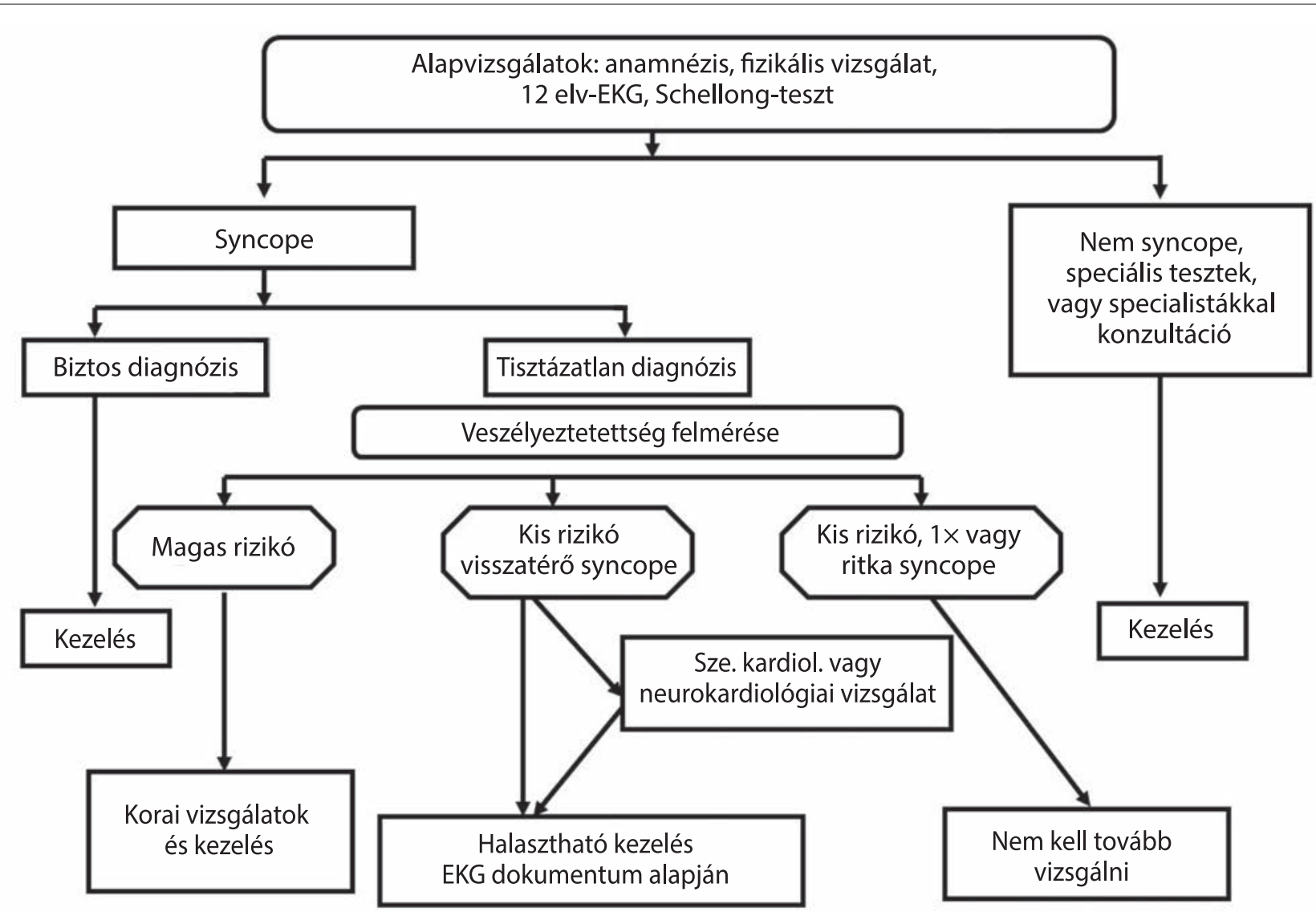

\section{5. ÁBRA. A syncope ellátási algoritmusa}

Amennyiben nem igazolódik aritmia, illetve organikus szívbetegség az ájulás hátterében, akkor a beteg tünetei, panaszai döntik el a további teendőket. Ismétlődő vagy súlyos tünetekkel járó esetekben ajánlatos a neurálisan mediált (reflex) syncopék irányában folytatni a kivizsgálást (head-up tilt table teszt, carotis sinus masszázs, implantálható eseményrögzítő). Egy pozitív eredményü teszt gyakran a pácienst is meggyőzi az ájulás ártalmatlan természetéről, $s$ ez pozitív hatást gyakorol a betegség zajlására. Az egyszeri, vagy ritkán előforduló ájulás jelentkezésekor a betegek többsége, nagy valószínúséggel szintén a neurálisan mediált syncopék csoportjába tartozik (különösen akkor, ha a roszszullét körülményei is erre utalnak). Ilyenkor általában nem szükséges kezelés, csupán a gondos követés és ellenőrzés ajánlott (1, 11, 12, 20, 21). Hangsúlyozzuk, hogy a statndardizált diagnosztikus algoritmusok alkalmazása javítja a betegek ellátásának minőségét, s csökkentik az ellátás költségeit is $(4,14,20)$.

\section{A közlemény föbb mondanivalójának kiemelése}

A syncope klinikai ellátása során nagyon fontos a pontos definíció alapján a helyes diagnózis felállítása. A jelenlegi útmutatók alapján az alapvizsgálatok (anamnézis, fizikális vizsgálat - benne az álló helyzetben is elvégzett artériás vérnyommérés, a 12 elvezetéses EKG) elvégzése az esetek több mint $50 \%$-ában pontos diagnózishoz vezet, ami alapján idejekorán elkezdhető az adekvát, sok esetben az azonnali életmentő kezelés. Ha az alapvizsgálatokkal nem sikerül tisztázni a syncope oka(i)t, részletes kardiológiai kivizsgálás (echokardiográfia, a terheléses vizsgálatok, sz.e. 24-48 órás ambuláns Holter EKG-, illetve hosszabb idejü eseményrögzítő EKG-monitorozás, klinikai szív elektrofiziológiai vizsgálat stb.) szükséges. Amennyiben kizárható az aritmia és az organikus szívbetegség lehetősége, ismétlődő vagy súlyos tünetekkel járó esetekben a neurálisan mediált (reflex) syncope irányában kell folytatni a kivizsgálást (head-up tilt table teszt, carotis sinus masszázs, implantálható eseményrögzítő stb.). A standardizált diagnosztikus algoritmusok alkalmazása javítja a betegek ellátásának minőségét, s csökkentik az ellátás költségeit is.

Irodalom

1. Az Oxiológiai- Sürgősségi, Honvéd- és Katasztrófaorvostani Szakmai Kollégium. A Nemzeti Erőforrás Minisztérium szakmai irányelve az ájulásról - Megítélés és kezelés a sürgősségi gyakor- 
latban. Egészségügyi Közlöny 2011; 61: 1491-1503.

http://www.kozlonyok.hu/kozlonyok/Kozlonyok/6/PDF/2011/7.pdf

2. Brignole M, Alboni P, Benditt D, et al. Task Force on Syncope, European Society of Cardiology. Guidelines on management (diagnosis and treatment) of syncope. Eur Heart J 2001; 22: 1256-1306. DOI: 10.1053/euhj.2001.2739.

3. Brignole M, Alboni P, Benditt DG, et al. Guidelines on management (diagnosis and treatment) of syncope - Update 2004. Europace 2004; 6: 67-537. DOI: 10.1016/j.eupc.2004.08.008

4. Brignole M, Hamdan MH. New Concepts in the Assessment of Syncope. J Am Coll Cardiol 2012; 59: 1583-91. DOI: 10.1016/j. jacc.2011.11.056

5. Cooper JN, Westby M, Pitcher DW, et al. Synopsis of the National Institute for Health and Clinical Excellence Guideline for Management of Transient Loss of Consciousness. Ann Intern Med 2011; 155: 543-549. DOI: 10.7326/0003-4819-155-8 201110180-00368

6. Costantino G, Sun BC, Barbic F, et al. Syncope clinical management in the emergency department: a consensus from the first international workshop on syncope risk stratifcation in the emergency department. Eur Heart J 2016; 37: 1493-1498. DOI:10.1093 eurheartj/ehv378

7. Freeman R, Wieling W, Axelrod FB, et al. Consensus statement on the definition of orthostatic hypotension, neurally mediated syncope and the postural tachycardia syndrome. Clin Auton Res 2011; 21: 69-72. DOI: 10.1007/s10286-011-0119-5

8. Huff JS, Decker WW, Quinn JV, et al. Clinical policy: Critical issues in the evaluation and management of adult patients presenting to the emergency department with syncope. Ann Emerg Med 2007; 49: 431-444. DOI: 10.1016/j.annemergmed.2007.02.001

9. Lahrmann $\mathrm{H}$, Cortelli $\mathrm{P}$, Hilz M, et al. EFNS guidelines on the diagnosis and management of orthostatic hypotension. Eur J Neurol 2006; 13: 930-936. DOI: 10.1111/j.1468-1331.2006.01512

10. Linzer M, Yang EH, Estes NA 3rd, et al. Diagnosing syncope. Part 1: value of history, physical examination, and electrocardiog raphy. Clinical Efficacy Assessment Project of the American College of Physicians. Ann Intern Med 1997; 126: 989-996. DOI: 10.7326/0003-4819-126-12-199706150-00012

11. Lőrincz I, Rudas L. A syncope diagnosztikája és terápiája. In
Kardiológiai Szakmai Kollégium (szerk.) Kardiológiai Útmutató: Diagnosztikus és terápiás irányelvek. Budapest: Medition Kiadó; 2011. 12. Moya A, Sutton R, Ammirati F, et al. Guidelines for the diagnosis and management of syncope (version 2009). Eur Heart J 2009; 21: 2631-2671. DOI: 10.1093/eurheartj/ehp298

13. Puppala VK, Dickinson O, Benditt DG. Syncope: classification and risk stratification. J Cardiol 2014; 63:171-7. DOI: 10.1016/j. jjcc.2013.03.019

14. Rosanio S, Schwarz ER, Ware DL, Vitarelli A. Syncope in adults: Systematic review and proposal of a diagnostic and therapeutic algorithm. Int J Cardiol 2013; 162: 149-57. DOl:10.1016/j. ijcard.2011.11.021

15. Saal DP, van Dijk JG. Classifying syncope. Auton Neurosci 2014;184:3-9. DOI: 10.1016/j.autneu.2014.05.007

16. Sheldon RS, Morillo CA, Krahn AD, et al. Standardizes approaches to the investigation of syncope: Canadian Cardiovascular Society position paper. Can J Cardiol 2011; 27: 246-253.DOI: 10.1016/j. cjca.2010.11.002

17. Strickberger SA, Benson DW, Biaggioni I, et al. AHA/ACCF scientific statement on the evaluation of syncope from the American Heart Association Councils on Clinical Cardiology, Cardiovascular Nursing, Cardiovascular Disease in the Young, and Stroke, and the Quality of Care and Outcomes Research Interdisciplinary Working Group; and the American College of Cardiology Foundation in collaboration with the Heart Rhythm Society. J Am Coll Cardiol 2006; 47: 473-484. DOI: 10.1016/j.jacc.2005.12.019.

18. Sutton R. Clinical classification of syncope. Prog Cardiovasc Dis 2013; 55: 339-44. DOI: 10.1016/j.pcad.2012.11.005

19. Sutton R. Carotid sinus syndrome: Progress in understanding and management. Glob Cardiol Sci Pract 2014; 2014: 1-8. DOI: $10.5339 /$ gcsp.2014.18

20. Walsh K, Hoffmayer K, Hamdan MH. Syncope: diagnosis and management. Curr Probl Cardiol 2015; 40: 51-86 DOl:10.1016/j.cp cardiol.2014.11.001

21. Win-Kuang Shen, Robert S. Sheldon,David G. Benditt, Mitchell I. Cohen, et al. 2017 ACC/AHA/HRS Guideline for the Evaluation and Management of Patients With Syncope: A Report of the American College of Cardiology/American Heart Association Task Force on Clinical Practice Guidelines, and the Heart Rhythm Society. Circula-

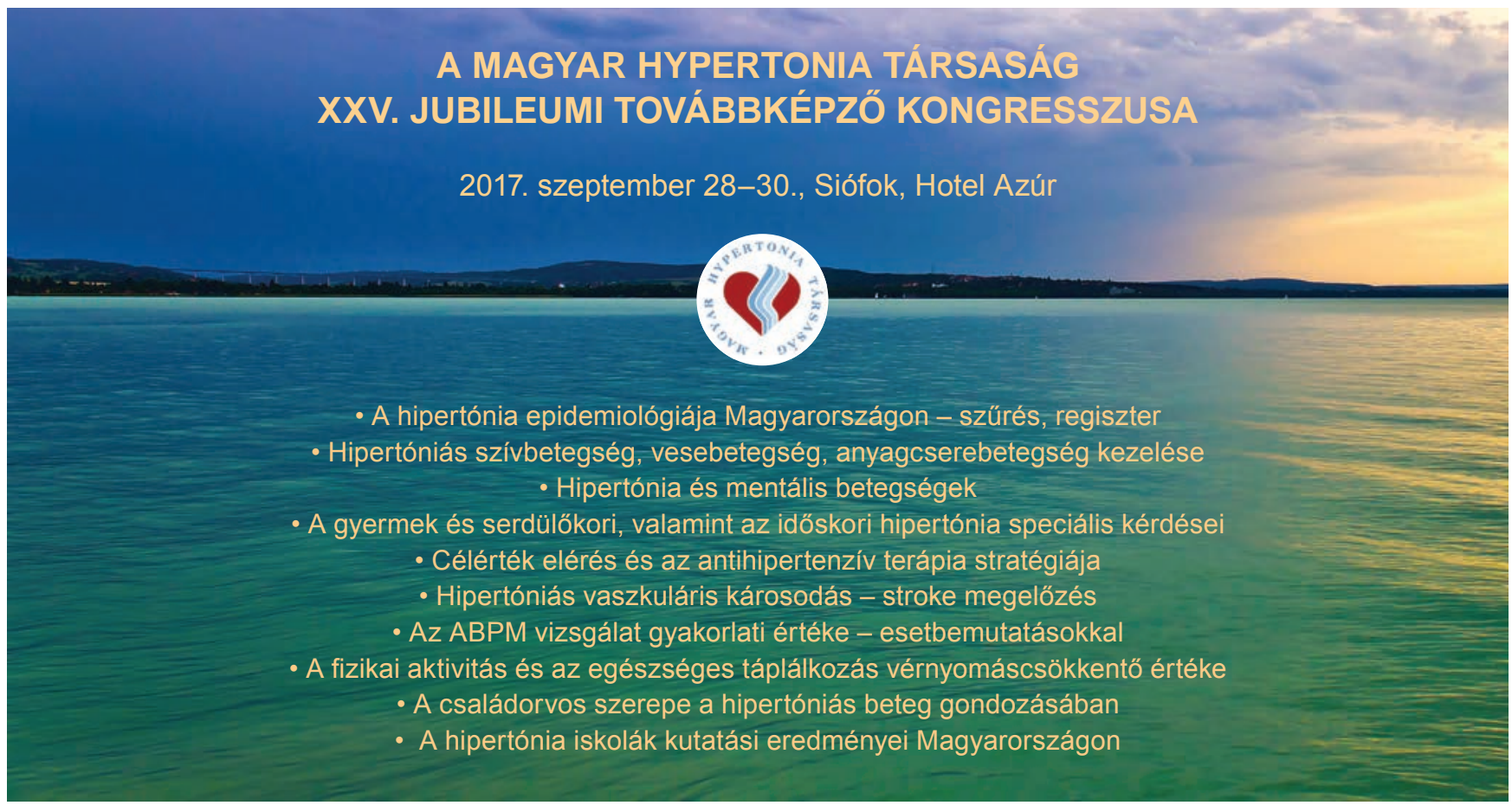

